\title{
Molecular bases of Sorcin-dependent resistance to chemotherapeutic agents
}

\author{
Ilaria Genovese ${ }^{1}$, Andrea llari $^{2}$, Theo Battista ${ }^{3}$, Valerio Chiarini ${ }^{4}$, Francesco Fazi ${ }^{5}$, Annarita Fiorillo ${ }^{3}$, \\ Gianni Colotti ${ }^{2}$ \\ 'Department of Radiology, Oncology and Pathology, Sapienza University of Rome, Rome 00161, Italy. \\ ${ }^{2}$ IBPM-CNR, Institute of Molecular Biology and Pathology, Italian National Research Council, Rome 00185, Italy. \\ ${ }^{3}$ Department of Biochemical Sciences, Sapienza University of Rome, Rome 00185, Italy. \\ ${ }^{4}$ Institute of Biotechnology, University of Helsinki, Helsinki 00014, Finland. \\ ${ }^{5}$ Department of Anatomical, Histological, Forensic Medicine \& Orthopedic Sciences, Sapienza University of Rome, laboratory \\ affiliated to Istituto Pasteur Italia-Fondazione Cenci Bolognetti, Rome 00161, Italy.
}

Correspondence to: Dr. Andrea Ilari, IBPM-CNR, Institute of Molecular Biology and Pathology, Italian National Research Council, Rome 00185, Italy. E-mail: andrea.ilari@uniroma1.it; Dr. Gianni Colotti, IBPM-CNR, Institute of Molecular Biology and Pathology, Italian National Research Council, Rome 00185, Italy. E-mail: gianni.colotti@uniroma1.it

\begin{abstract}
How to cite this article: Genovese I, Ilari A, Battista T, Chiarini V, Fazi F, Fiorillo A, Colotti G. Molecular bases of Sorcin-dependent resistance to chemotherapeutic agents. Cancer Drug Resists2018;1:164-80. http://dx.doi.org/10.20517/cdr.2018.10
\end{abstract}

Received: 28 Jun 2018 First Decision: 9 Aug 2018 Revised: 16 Aug 2018 Accepted: 20 Aug 2018 Published: 19 Sep 2018

Science Editors: Elisa Giovannetti, Jose Antonio Rodriguez Copy Editor: Yuan-Li Wang Production Editor: Cai-Hong Wang

\begin{abstract}
Soluble resistance-related calcium binding protein (Sorcin) is a protein initially labelled "resistance-related", since it is co-amplified with $A B C B 1$ in multidrug (MD)-resistant cells. While for years Sorcin overproduction was believed to be a by-product of the co-amplification of its gene with the P-glycoprotein gene, many recent studies view Sorcin as an oncoprotein, playing an important role in MD resistance (MDR). Sorcin is one of the most highly expressed calciumbinding proteins, which is overexpressed in many human tumors and MD resistant cancers, and represents a novel MDR marker. Sorcin expression in tumors inversely correlates with patients' response to chemotherapies and overall prognosis. Sorcin is highly expressed in MDR cell lines over their parent cells. Sorcin overexpression by gene transfection increases drug resistance to a variety of chemotherapeutic drugs in many cancer lines. On the other hand, Sorcin silencing leads to reversal of drug resistance in many cell lines. This review describes: (1) the roles of Sorcin in the cell; (2) the studies showing Sorcin overexpression in tumors and cancer cells; (3) the studies showing the effects of Sorcin overexpression and silencing; (4) the molecular effects of Sorcin overexpression; and (5) the structural and genetic bases of Sorcin-dependent MDR.
\end{abstract}

Keywords: Sorcin, calcium, cancer, multidrug resistance in cancer, doxorubicin, endoplasmic reticulum, heart, brain, ryanodine receptors, ER stress

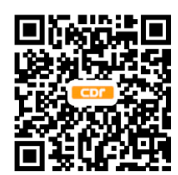




\section{SORCIN STRUCTURE AND ACTIVATION}

Soluble resistance-related calcium binding protein (Sorcin) was named "resistance-related" since it was found to be co-amplified with ABCB1 in multidrug (MD)-resistant cells ${ }^{[1]}$. The gene coding for Sorcin (SRI) is located in the chromosome region 7q21 and is about $21.9 \mathrm{~kb}$-long. At least four alternative Sorcin isoforms are transcribed, i.e., isoforms $\mathrm{A}$ (a transcript of $15 \mathrm{~kb}$ with eight exons and seven introns, translated into a 198-residues long, 22-kDa Sorcin), B, C and D, translated into shorter 19-kDa isoforms, where part of the $\mathrm{N}$-terminal domain and/or of the last aminoacids of the C-terminal domain are missing. Most literature refers to isoform A, although a few studies deal about $19-\mathrm{kDa}$ form of Sorcin. The pseudogene Sorcin-like (SRIL) is in the chromosomal region $4 \mathrm{q} 12^{[2]}$.

Sorcin is present in vertebrates, and more generally in metazoans. Its sequence is highly conserved among species: protein sequences of mouse and human Sorcin show only eight differences, concentrated in the second half of the protein, and six of them regard possibly phosphorylatable serine and threonine residues, indicating that species-specific phosphorylation-dependent regulation of Sorcin may occur.

Usually calcium-binding proteins contain an even number of EF-hands, paired both structurally and functionally. Sorcin belongs to the small penta-EF-hand (PEF) family, containing an odd (5) number of EFhands. Sorcin is a homodimer, although heterodimerization with another PEF protein, grancalcin, has been observed $^{[3,4]}$. Sorcin monomers are formed by two domains, i.e., a rather short, flexible, glycine- and prolinerich $\mathrm{N}$-terminal domain and a C-terminal domain Sorcin calcium-binding domain (SCBD), globular and composed by eight alpha-helices, which form five EF-hands (EF1-5) [Figure 1].

EF-hands couple through short $\beta$-sheets: EF1 pairs with EF2; EF3 pairs with EF4; the odd EF5 pairs with another EF5, belonging to the other monomer, forming part of the dimeric interface. The dimer contains five EF pairs and can be considered the structural unit of Sorcin. The long and rigid D- and G-helices connect different EF-hands pairs, with the D-helix belonging to both EF2 and EF3, and the G-helix connecting EF4 and EF5. The SCBD can be divided in two subdomains: the EF1-3 subdomain (residues 33-134) is composed by the three EF-hands that bind calcium with high affinity, while the EF4-5 subdomain (residues 135-198) mediates dimerization, contains many potential phosphorylation sites, but does not bind $\mathrm{Ca}^{2+}$ with high affinity. Calcium binding to EF hands determines the transition from a "closed" structure to an "open" structure ${ }^{[5,6]}$. Binding of calcium to EF3, the highest-affinity calcium-binding motif, EF2 and EF1 sites activate Sorcin: $\mathrm{Ca}^{2+}$ binding to EF3 alters the conformation of the loop containing Glu124, and this change is transmitted to EF2 via a movement of the long D-helix connecting EF3 with EF2. Overall, calcium binding to the EF1-3 hands promotes a large conformational change in Sorcin structure, involving a movement of the long D-helix and the opening of EF1, with the two subdomains moving away of $21^{\circ}$ [Figure 1]. This movement determines the exposure to solvent of hydrophobic residues of the D-helix, of the EF loop and of the G-helix, with a consequent dramatic decrease of solubility, thus allowing Sorcin to translocate from cytosol to membranes, and to bind and regulate a series of target proteins ${ }^{[6-9]}$. The hydrophobic pocket can accommodate in $\mathrm{Ca}^{2+}$-bound Sorcin a portion of the $\mathrm{N}$-terminal domain displaying the consensus binding motif identified by phage display experiments [Figure 2].

\section{THE ROLES OF SORCIN IN THE CELL: SORCIN LOCALIZATION, CELL CYCLE, AND FUNCTIONS} IN THE CELL

Sorcin is one of the most expressed human calcium binding proteins; it is expressed in most human tissues, at high levels in bone, heart, brain, B- and T-lymphocytes, monocytes, kidney, breast and skin (sources: MOPED, PaxDb and MaxQB databases) ${ }^{[2]}$. In addition, Sorcin is overexpressed in many cancer types, and especially in MD-resistant cells (see below). Cell localization of Sorcin is dynamic. During interphase Sorcin is localized in the nucleus, in the cytosol, in the plasma membranes, at the endoplasmic reticulum 


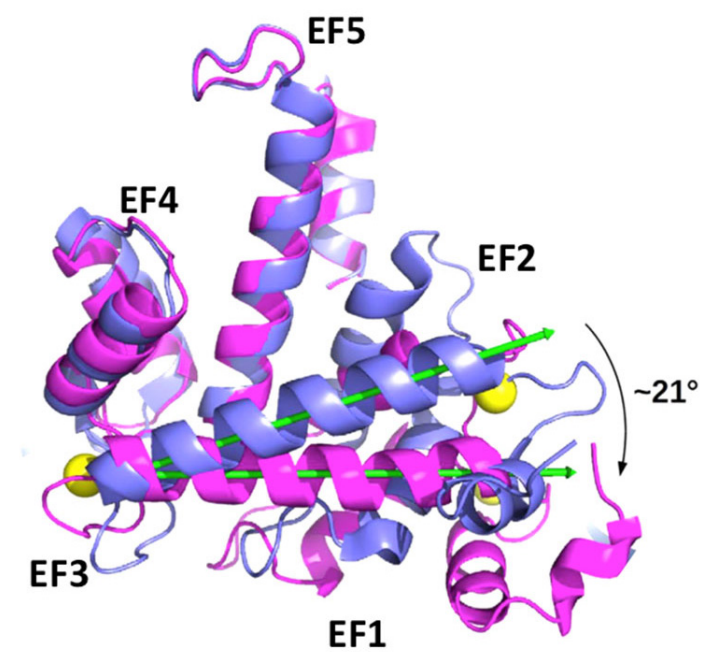

Figure 1. X-ray crystal structure of human sorcin in the apo (blue) and calcium-bound (magenta) forms $\mathrm{s}^{[5]}$
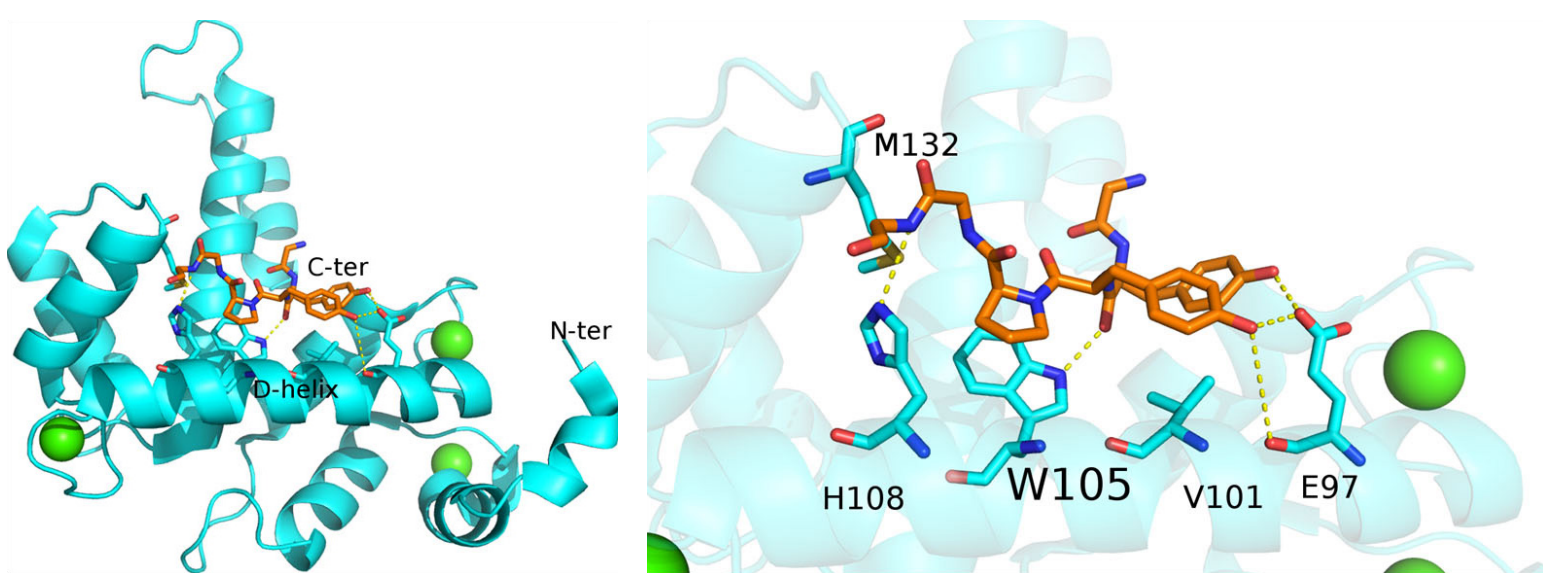

Figure 2. A: In human sorcin, upon calcium binding, the conformational change determines exposure of hydrophobic residues, that are able to bind ligands; B: in the X-ray crystal structure of sorcin, part of the hydrophobic N-terminal domain (brown) results bound to residues of the $\mathrm{D}$-helix

(ER) and in ER-derived vesicles along the microtubules, containing ryanodine receptors (RyRs), ER Ca ${ }^{2+}$ ATPase (SERCA), calreticulin and Rab10 ${ }^{[10]}$. The shorter $19-\mathrm{kDa}$ Sorcin variant was found localized at the mitochondrion $^{[11]}$. During mitosis, Sorcin localizes in the cleavage furrow during late telophase, and at the midbody before cytokinesis ${ }^{[10]}$.

In the cytosol, $\mathrm{Ca}^{2+}$ concentration is maintained below $100 \mathrm{~nm}$ since on one side it is actively pumped from the cytosol to the extracellular space, into ER and into mitochondria, and on the other many proteins bind $\mathrm{Ca}^{2+}$, contributing to calcium buffering ${ }^{[12]}$. Sorcin participates in the regulation of $\mathrm{Ca}^{2+}$ homeostasis by many mechanisms. Sorcin is able to bind $\mathrm{Ca}^{2+}$ in the micromolar range, thereby participating in cation buffering. More importantly, $\mathrm{Ca}^{2+}$-bound Sorcin can interact with RyR and ER $\mathrm{Ca}^{2+}$ ATPase (SERCA), located in the ER, with the L-type calcium channel Cav1 and $\mathrm{Na}^{+}-\mathrm{Ca}^{2+}$ exchangers (NCX), located in the plasma membrane, and regulates them: Sorcin increases ER $\mathrm{Ca}^{2+}$ storage by activating SERCA and by inhibiting RyR [Figure 3], increases size and $\mathrm{Ca}^{2+}$ load of ER-derived vesicles, and increases mitochondrial $\mathrm{Ca}^{2+}$ concentration $^{[7,8,10,11,13-19]}$.

High Sorcin expression increases ER $\mathrm{Ca}^{2+}$ concentration, can prevent ER stress and the unfolded protein response, and increases escape from apoptosis ${ }^{[10]}$. Sorcin is necessary for normal glucose tolerance and 


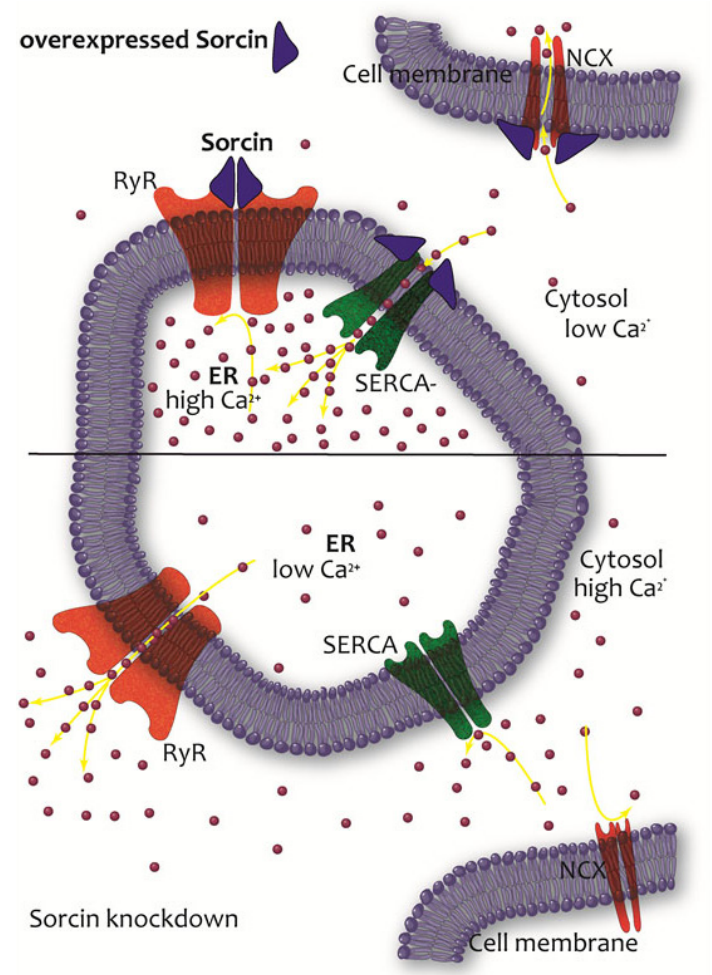

Figure 3. Sorcin inhibits the ryanodine receptor and up-regulates ER Ca ${ }^{2+}$ ATPase (SERCA) and $\mathrm{Na}^{+}-\mathrm{Ca}^{2+}$ exchangers (NCX), increasing $\mathrm{Ca}^{2+}$ load of the endoplasmic reticulum (ER) (and possibly of mitochondria) and decreasing ER stress

protects against lipotoxicity in vivo, is able to induce ATP-evoked $\mathrm{Ca}^{2+}$ release from intracellular stores and induces glucose-stimulated insulin secretion ${ }^{[20,21]}$. Sorcin represses the glucose-6-phosphatase catalytic subunit-2 promoter activity through NFAT activation, activates ATF6 transcriptional activity while repressing ER stress markers as $\mathrm{CHOP}$ and $\mathrm{Grp} 78 / \mathrm{BiP}^{[20]}$. Conversely, Sorcin silencing activates apoptotic proteases as caspase-3 and caspase-12, Grp78/BiP, Bcl-2, Bax, c-jun, c-fos and release of cytochrome c, results in major mitosis and cytokinesis defects, blocks cell cycle progression in mitosis, increases the formation of rounded, polynuclear cells and induces apoptosis ${ }^{[10,18,22]}$. Sorcin increases basal and caffeine-stimulated mitochondrial $\mathrm{Ca}^{2+}$ concentration $^{[18]}$; the folding and expression of the mitochondrial 19-kDa Sorcin isoform is regulated by $\operatorname{TRAP}^{[11]}$.

Sorcin contains several potential phosphorylation sites, and also interacts in a $\mathrm{Ca}^{2+}$-dependent fashion with many serine-threonine kinases, which participate in the regulation of mitosis progression, such as Akt2, Csnk2A1, Csnk2A2, polo-like kinase 1 (Plk1), Aurora A and Aurora B. Sorcin is phosphorylated by Plk1, induces Plk1 autophosphorylation, and participates in Plk1 regulation ${ }^{[10]} ; \mathrm{Ca}^{2+}$-calmodulin dependent kinase II (CaMKII) and cAMP-dependent protein kinase (PKA) phosphorylate Sorcin, thereby regulating Sorcin binding to RyRs and SERCA and $\mathrm{Ca}^{2+}$ homeostasis ${ }^{[6,23]}$.

Sorcin has been identified in other types of vesicles, other than the ER-dependent ones. Sorcin is present in nanovesicles released in a $\mathrm{Ca}^{2+}$-dependent fashion from the erythrocytes and containing Annexin $\mathrm{A} 7^{[24]}$; Sorcin was found to interact with Annexins A7 and $\mathrm{A} 11^{[7,8,10,15,25]}, \mathrm{Ca}^{2+}$-dependent phospholipid-binding proteins, the latter being required for midbody formation and completion of the terminal phase of cytokinesis ${ }^{[26]}$.

Sorcin has been identified in many types of exosomes from different sources, such as B-cells, mesenchymal stem cells, human urine, platelets and from many types of tumor cells, as colorectal cancer, ovarian cancer, prostate cancer cells, squamous carcinoma and neuroblastoma ${ }^{[27-35]}$. 
The microRNA miR-1 targets Sorcin specifically and non-redundantly; miR-1 decreases Sorcin levels, while the antagomiR-1 increases Sorcin expression ${ }^{[36]}$; treatment with miR-1 determines $\mathrm{Ca}^{2+}$ signaling dysregulation, especially at cardiac level.

Sorcin contributes to regulate $\mathrm{Ca}^{2+}$ homeostasis and cardiac excitation-contraction-relaxation processes. Excitation-contraction-relaxation is a fast $(800 \mathrm{~ms})$ process, started by the electrical excitation of cardiomyocytes by a wave of depolarization that opens voltage-dependent $\mathrm{Na}^{+}$channels located in the T-tubules, determining a rapid membrane depolarization and $\mathrm{Ca}^{2+}$ influx via voltage-operated $\mathrm{Ca}^{2+}$ channels (mainly Cav1 L-type channels). Cav1 channels (with four subunits Cav1.1, Cav1.2, Cav1.3, Cav1.4) are juxtaposed to ryanodine receptors (RyRs), i.e., sarcoplasmic reticulum (SR) or ER $\mathrm{Ca}^{2+}$ release channels. $\mathrm{Ca}^{2+}$ entry via Cav1 increases $\mathrm{Ca}^{2+}$ concentration near RyRs, triggering $\mathrm{Ca}^{2+}$ release from the SR. This flux further raises the free intracellular $\mathrm{Ca}^{2+}$ concentration $\left[\mathrm{Ca}^{2+}\right]_{\mathrm{I}}$ of the cardiomyocyte: $\mathrm{Ca}^{2+}$ binds to troponin $\mathrm{C}$ and triggers contraction. For relaxation to take place, $\mathrm{RyR}$ is closed and $\mathrm{Ca}^{2+}$ is pumped out of the cytosol, mainly via the SR $\mathrm{Ca}^{2+}$-ATPase (SERCA), which pumps $\mathrm{Ca}^{2+}$ back into the SR, and the sarcolemmal (and mitochondrial) $\mathrm{Na}^{+} / \mathrm{Ca}^{2+}$ exchanger $(\mathrm{NCX})^{[37]}$ : $\left[\mathrm{Ca}^{2+}\right]_{\mathrm{i}}$ decreases rapidly and $\mathrm{Ca}^{2+}$ dissociation from the myofilaments can occur.

Sorcin is able to interact with all the channels, exchangers and pumps responsible for $\mathrm{Ca}^{2+}$ fluxes during the excitation-contraction-relaxation process, and to regulate them. Sorcin modulates Cav1, by interacting with its Cav1.2 (CACNA1C) subunit with its C-terminal domain, slowing its $\mathrm{Ca}^{2+}$-dependent inactivation and stimulating voltage-dependent inactivation of Cav1-dependent $\mathrm{Ca}^{2+}$ currents $^{[13,14]}$.

Sorcin also $\mathrm{Ca}^{2+}$-dependently interacts with RyR2, the most expressed cardiac RyR, and strongly inhibits it, thereby reducing $\mathrm{Ca}^{2+}$ efflux from SR/ER by decreasing RyR mean open time and frequency of open event ${ }^{[8,15,17]}$. Sorcin is also able to interact with SERCA and to activate it ${ }^{[16]}$, and to activate NCX via $\mathrm{Ca}^{2+}-$ dependent interaction of the respective C-terminal, calcium binding domains; Sorcin overexpression in cardiomyocytes has also been associated with increased NCX activity ${ }^{[19,38]}$. Fast rates of association and of dissociation between Sorcin and NCX allows NCX regulation on a "beat to beat" basis.

Overall, Sorcin regulates the excitation-contraction-relaxation processes in the heart and muscle: Sorcin terminates the excitation-contraction processes, by inhibiting $\mathrm{Ca}^{2+}$-induced $\mathrm{Ca}^{2+}$ release by the SR, helps $\left[\mathrm{Ca}^{2+}\right]$ decreasing and induces relaxation by inhibiting RyR2-dependent calcium release from the SR, by activating SERCA2-dependent calcium pumping from cytosol to the SR and by increasing NCX-dependent $\mathrm{Ca}^{2+}$ efflux through the sarcolemma (and possibly into the mitochondrion) [Figure 3].

Sorcin phosphorylation alters its $\mathrm{Ca}^{2+}$-dependent activation, its translocation to the SR and the ability to regulate RyR2 activity. Sorcin is hyperphosphorylated in the failing heart; this increases Sorcin translocation to the SR membrane and the SR $\mathrm{Ca}^{2+}$ content and possibly results in the reduction of SR stress, in the reduction of basal $\left[\mathrm{Ca}^{2+}\right]_{\mathrm{i}}$ and in improvement of cardiac relaxation ${ }^{[16,23,39]}$.

The mutation F112L, located in the EF3 hand and associated with a familiar form of hypertrophic cardiomyopathy and hypertension, as other mutations in the EF3 and/or in the D-helix of Sorcin decreases the capacity of Sorcin to interact with RyR and to modulate $\mathrm{SR} \mathrm{Ca}{ }^{2+}$ release, and determines complex cardiac alterations ${ }^{[15,40]}$. In failing heart, levels of SERCA2a and of RyR2 are often decreased, and consequent altered cytosolic $\mathrm{Ca}^{2+}$ transients lead to abnormal contraction. Sorcin overexpression in mice increases cardiac contractility in the normal heart and determines a rescue of the abnormal contractile function of the diabetic heart, possibly due to improved $\mathrm{Ca}^{2+}$ transients ${ }^{[40-43]}$, while Sorcin $\mathrm{KO}$ mice present ventricular arrhythmia and sudden death when challenged by acute stress ${ }^{[4]}$. 
Sorcin has a very high expression level in the brain, 5-10 times higher than in the heart. Sorcin is one of the most expressed $\mathrm{Ca}^{2+}$ binding proteins in the prefrontal cortex, in the amygdala, in the hypothalamus and in many brain tumors (GeneAtlas). The extent of Sorcin expression and its ability to regulate $\mathrm{Ca}^{2+}$ homeostasis make Sorcin a potentially important protein in brain function and dysfunction. According to the so-called "Calcium Hypothesis", deregulation of $\mathrm{Ca}^{2+}$-mediated signaling, perturbed $\mathrm{ER} \mathrm{Ca}^{2+}$ homeostasis and ER stress are at the basis of the abnormal accumulation and aggregation of specific proteins, which are deposited in intracellular inclusions or extracellular aggregates during brain aging and in many neurodegenerative diseases, as Alzheimer's disease (AD) and Parkinson's disease (PD) ${ }^{[45]}$. PD is characterized by progressively distributed Lewy pathology and neurodegeneration, linked to the degeneration of dopaminergic neurons in the substantia nigra pars compacta. $\mathrm{Ca}^{2+}$ entry through Cav1 channels, mitochondrial oxidant stress and PD pathogenesis are strictly linked ${ }^{[46]}$. Alterations in RyR expression and function are observed in cells bearing familial mutations in the genes of the $\beta$-amyloid precursor protein ( $\beta A P P)$ and of presenilins (the catalytic core of $\gamma$-secretase complexes that cleave the $\beta$ APP to generate amyloid $\beta$-peptides), in the brain of transgenic AD mice models and in AD-affected human brains. RyR participates in the control of $\beta A P P$ processing and of $A \beta$ peptide production: RyR alteration or mysfunction alters neuronal death, synaptic function and memory and learning abilities ${ }^{[4]}$, and its regulation by Sorcin can be important in maintaining $\mathrm{ER} \mathrm{Ca}^{2+}$ load in ER and possibly decreasing ER stress and unfolded protein production in the brain. Further, Sorcin is able to directly interact as a function of $\mathrm{Ca}^{2+}$ concentration (in vitro, in cultured cells and in human brain) with alpha-synuclein (AS) and presenilin 2 (PS2), important in PD and AD pathogenesis, respectively ${ }^{[48,49]}$. Sorcin binds to the C-terminal part of PS2 that forms low-conductance $\mathrm{Ca}^{2+}$ channels in planar lipid bilayers ${ }^{[50]}$, interacts with $\mathrm{RyR}$ in a $\mathrm{Ca}^{2+}$-dependent fashion, and regulates $\mathrm{Ca}^{2+}$ homeostasis ${ }^{[51]}$. Sequestration of Sorcin by aberrant forms of tau compromises its function, impairing calcium homeostasis and cellular resistance by ER stress, and contributing to the progression of $\mathrm{AD}^{[52]}$. Sorcin is overexpressed in a PD cell model induced by 1-methyl-4-phenylpyridinium ion $\left(\mathrm{MPP}^{+}\right)$in SH-SY5Y cells ${ }^{[53]}$, which is one of the most differentially expressed proteins in PD vs. normal human substantia nigra ${ }^{[54]}$ and in PD $v s$. human brain samples ${ }^{[55]}$, and is overexpressed in $\mathrm{AD}$ brain samples ${ }^{[56-58]}$, in particular in sporadic $\mathrm{AD}^{[59]}$ and in $\mathrm{AD}$ brains with severe cerebral amyloid angiopathy ${ }^{[00]}$, as well as in frontal cortical tissues from postmortem cases of frontotemporal dementia ${ }^{[61]}$. Further, Sorcin is overexpressed in 7 different Huntington's disease human and mice models, where it has been associated with the unfolded protein respons ${ }^{[62]}$. Sorcin also interacts with the ionotropic glutamate receptor NMDAR1 $\mathrm{Ca}^{2+}$ channel, important in several cascade pathways and in synaptic plasticity, in caudate-putamen nucleus ${ }^{[63]}$, and with annexins A7 and A11, involved in $\mathrm{Ca}^{2+}$ homeostasis in astrocytes ${ }^{[64]}$.

\section{SRI OVEREXPRESSION IN MD-RESISTANT CANCERS, SORCIN ROLES IN MD RESISTANCE}

Sorcin was isolated in 1981 as a soluble protein expressed in hamster lung tumor cells resistant to vincristine, and named according to its main characteristics as soluble, resistance-related, calcium binding protein $\left(\right.$ Sorcin ${ }^{[65]}$. Sorcin is overexpressed in different tumors, from many tissues, mostly with an ABCB1-dependent MD-resistant phenotype. The SRI gene resides in the same amplicon of ABCB1, in chromosome 7q21.12, and was identified as a resistance-related gene because often its gene is co-amplified with ABCB1 in MD-resistant cancer cells ${ }^{[1]}$. For two decades, Sorcin overexpression was believed to be an accidental by-product of this genomic co-amplification process ${ }^{[6]}$; in the last 15 years many studies have defined Sorcin as an oncoprotein, characterized both as a marker and a cause of MD resistance (MDR).

Sorcin is overexpressed in many human cancers, including adenocarcinoma, breast cancer, colorectal cancer, gastric cancer, lung cancer, nasopharyngeal cancer, hepatocellular carcinoma and ovarian cancer, lymphoma, leukemia and myeloma, and particularly in cancers with ABCB1-dependent MD-resistant phenotype ${ }^{[67-81]}$. The level of expression of Sorcin is one of the main markers of poor outcome in embryonal tumors of central nervous system ${ }^{[8]}$; Sorcin is a histological marker for malignant glioma, and is overexpressed in anaplastic astrocytoma, glioblastoma and oligodendroglioma ${ }^{[33-86]}$. 


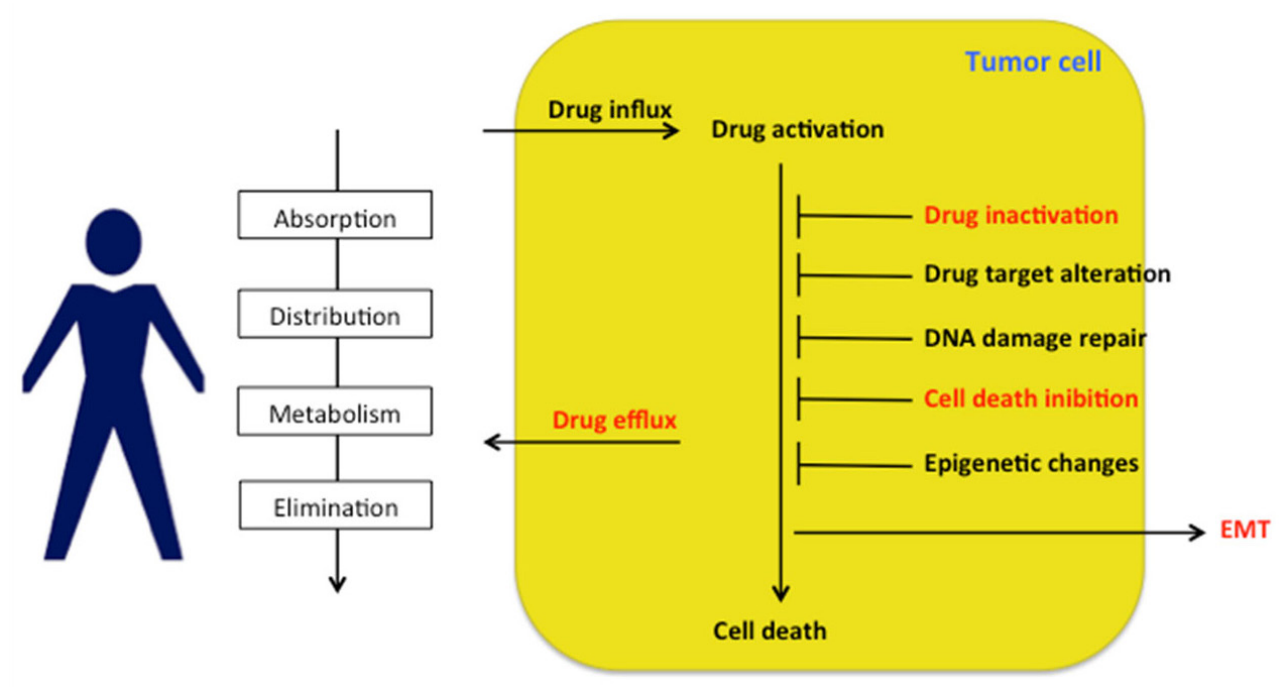

Figure 4. Multidrug-resistance (MDR) depends on a series of factors, including absorption, distribution, metabolism, elimination (ADME), drug influx and efflux, drug activation/inactivation, drug target alteration, DNA damage repair, cell death inhibition, epigenetic alteration and epithelial-to-mesenchymal transition (EMT). Sorcin contributions to the onset of a MD-resistant phenotype are indicated in red (see text)

Sorcin is an oncoprotein with multifaceted activity in both tumorigenesis and the onset of a MD-resistant phenotype [Figure 4]. Sorcin, by loading calcium in ER and mitochondria, prevents ER stress and possibly the unfolded protein response, and increases cell escape from apoptosis ${ }^{[10,11,78]}$; in MD-resistant tumor cells overexpressing Sorcin, the equilibrium between cell life and death is shifted towards proliferation.

In doxorubicin-resistant leukemia cell lines, Sorcin is overexpressed with respect to the drug-sensitive parental cell line. In leukemia patients, Sorcin expression level correlates with low-response to chemotherapies and poor prognosis; Sorcin overexpression (with gene transfection techniques) increases MDR to doxorubicin, vincristine, etoposide and homoharringtonine in leukemia K562 cells and in lung tumors, to doxorubicin, vincristine, paclitaxel and 5-fluorouracil in SGC7901 cells, ovarian and breast cancer ${ }^{[22,69,72,74,76,87]}$. Conversely, Sorcin silencing reverses MDR in many tumor cell lines, as MD-resistant leukemia and Sorcin-transfected leukemia cells, breast cancer, HeLa, colorectal cancer and nasopharyngeal carcinoma cells ${ }^{[2,22,74-78,88-94]}$. In a lung cancer cell line, Sorcin silencing decreases $\mathrm{ABCB} 1$ protein levels and $\mathrm{ABCB} 1$ activity, thereby decreasing rhodamine123 efflux ${ }^{[87]}$ [Table 1].

Sorcin is also able to bind directly and with high affinity several chemotherapeutic drugs, as doxorubicin, paclitaxel, vinblastine and cisplatin; Sorcin acts as a cytosolic drug scavenger, thereby reducing doxorubicin nuclear uptake, and allowing an increase of drug resistance and of cell survival ${ }^{[87]}$. Sorcin binds doxorubicin with high affinity in a site at the EF5 hand, which is involved in Sorcin dimerization and does not bind calcium with high affinity [Figure 5], and changes cell localization upon doxorubicin treatment, and presumably upon drug binding ${ }^{[87]}$.

Sorcin overexpression increases migration, invasion and metastasis in vitro, while Sorcin silencing inhibits the epithelial-to-mesenchymal (EMT) transition in a human breast cancer cell line, possibly via E-cadherin and VEGF expression, and reduces breast cancer metastasis ${ }^{[94]}$. Sorcin induces migration and invasion also in gastric cancer cells, while inhibition of Sorcin expression down-regulates the expression of markers of invasion, migration and proliferation as MMP2, MMP9, CTSZ and p-STAT3, followed by suppression of tumor growth and metastasis ${ }^{[95]}$. Sorcin interacts with STAT3 and increases its phosphorylation, thereby negatively regulating NF- $\kappa$ B signaling ${ }^{[96]}$. 


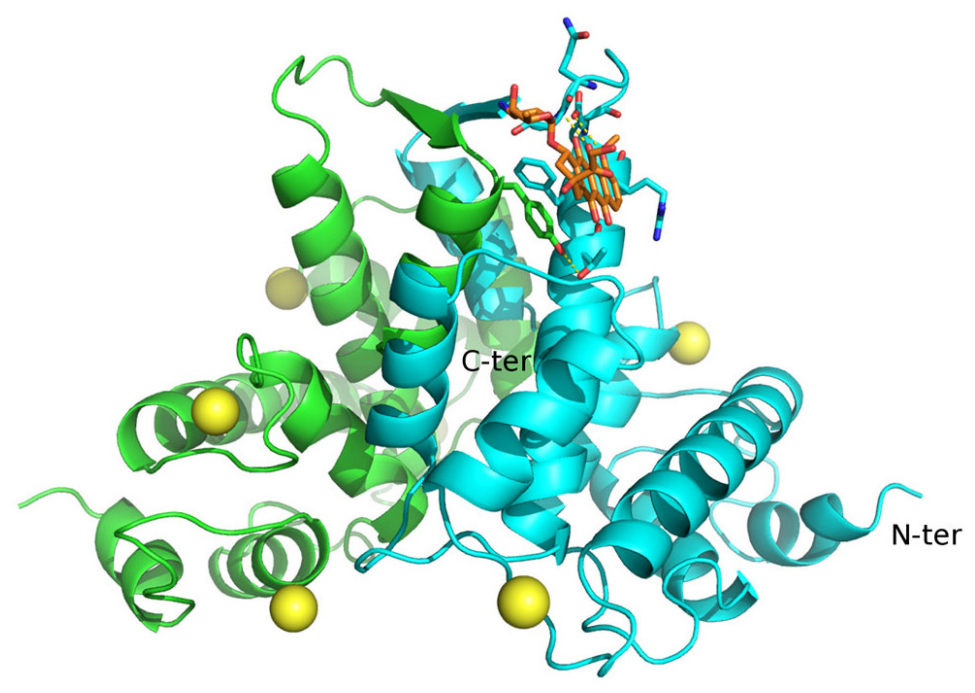

Figure 5. Sorcin is able to bind with high affinity doxorubicin and other drugs: the crystal structure of the sorcin-doxorubicin complex shows that the drug binds to the EF5 hand ${ }^{[87]}$

Table 1. Selected studies on the effects of sorcin overexpression and/or silencing in tumor cell lines

\begin{tabular}{|c|c|c|c|}
\hline Tumor cell lines & Resistance & $\begin{array}{l}\text { Overexpression (O), } \\
\text { silencing (S) }\end{array}$ & Reference \\
\hline Leukemia (K562), breast cancer (MCF-7) & Doxorubicin & $\mathrm{O}, \mathrm{S}$ & 22 \\
\hline Leukemia (K562) & Doxorubicin & $\mathrm{O}$ & 69 \\
\hline Leukemia (K562) & Doxorubicin, vincristine & $\mathrm{O}, \mathrm{S}$ & 72 \\
\hline Leukemia (K562) & $\begin{array}{l}\text { Doxorubicin, etoposide, Homoharringtonine, } \\
\text { vincristine }\end{array}$ & $\mathrm{O}, \mathrm{S}$ & 74 \\
\hline Lung adenocarcinoma (A549) & Cisplatin & S & 75 \\
\hline Leukemia (K562), breast cancer (MCF-7) & Adriamycin & $\mathrm{S}$ & 76 \\
\hline Leukemia (CCRF-CEM) & Methotrexate & 0 & 77 \\
\hline Colorectal cancer (CRC) & 5-fluorouracil, oxaliplatin, irinotecan & $\mathrm{O}, \mathrm{S}$ & 78 \\
\hline Lung cancer (H1299) & Doxorubicin & $0, \mathrm{~S}$ & 87 \\
\hline Leukemia (K562) & Adriamycin & $\mathrm{O}$ & 88 \\
\hline Gastric cancer (SGC7901) & Vincristine, adriamycin, taxol, 5-fluorouracil & $\mathrm{O}, \mathrm{S}$ & 89 \\
\hline Cervical carcinoma (HeLa) & Vinblastine & $0, \mathrm{~S}$ & 90 \\
\hline Nasopharingeal carcinoma (CNE2) & Cisplatin & S & 91 \\
\hline Ovarian carcinoma (2008) & Paclitaxel & O & 92 \\
\hline Breast cancer & Neoadjuvant chemotherapy & $\mathrm{O}$ & 93 \\
\hline $\begin{array}{l}\text { Breast cancer (MDA-MB-231), lung } \\
\text { adenocarcinoma (A549), lung fibrosarcoma } \\
\text { (HT1080) }\end{array}$ & Adriamycin, etoposide & $\mathrm{O}, \mathrm{S}$ & 94 \\
\hline
\end{tabular}

Sorcin expression is upregulated in hepatocellular carcinoma, with respect to adjacent non-tumor liver tissues and to normal liver tissues. Sorcin expression correlates with hepatocellular carcinoma metastasis: patients with high Sorcin expression have shorter survival and higher recurrence compared with patients with low Sorcin expression. Sorcin increases proliferation, migration, and invasion in vitro in hepatocellular carcinoma and colorectal cancer cell, and facilitates cancer growth, metastasization and EMT, via activation of ERK and/or PI3K/Akt signaling pathways ${ }^{[7,99]}$. Sorcin is also involved in the regulation of $\mathrm{Ca}^{2+}$-mediated angiogenesis, via the VEGF/PI3K/Akt pathway in endometrial cells and plays a crucial role in preparing the endometrium for implantation ${ }^{[98]}$.

Sorcin induces the expression of $\mathrm{ABCB} 1$ via a cAMP response element (CRE), located between -716 and -709 base pairs upstream the ABCB1 gene: Sorcin overexpression increases CRE-binding protein (CREB) phosphorylation and its binding to the $\mathrm{CRE}$ site in the $\mathrm{ABCB} 1$ promoter induces $\mathrm{ABCB} 1$ expression $^{[72]}$. 
In the mitochondrion, Sorcin interacts with TRAP1, a mitochondrial chaperone with antioxidant and antiapoptotic protein, upregulated in several human tumors. TRAP1 modulates apoptosis by exerting a quality control on the short $(19-\mathrm{kDa})$ mitochondrial Sorcin isoform. TRAP1 silencing in colorectal carcinoma cells decreases mitochondrial Sorcin expression, and Sorcin silencing increases TRAP1 degradation, while overexpression of a TRAP1 mutant localized in the ER increases the expression of mitochondrial Sorcin and protects from paclitaxel-dependent apoptosis ${ }^{[11]}$. Sorcin overexpression increases ER and mitochondrial calcium levels, while Sorcin silencing activates caspase-3, caspase-12 and GRP78/BiP, increases mitotic defects, blocks cell cycle progression in $\mathrm{G} 2 / \mathrm{M}$, increases the number of rounded polynucleated cells and induces apoptosis and cell death ${ }^{[10,22,78]}$. Sorcin overexpression in leukemia cells increases expression of Bcl-2 and decreases Bax levels ${ }^{[22]}$.

Sorcin is an interesting oncoprotein and MDR marker, expressed in many cancer cell types, and whose overexpression results in the MDR phenotype. Sorcin has an important role in calcium homeostasis, and is able to interact/regulate several targets and to contribute to the onset of a MD-resistant phenotype in different ways.

Sorcin has no enzymatic activity, and targeting its activity may prove difficult. The modulation of Sorcin expression and activity for overcoming tumorigenesis, cancer-related EMT and MDR is a possible target: small molecules as dihydromyricetin have been used to target Sorcin, and administration of extracts from plants as Tegillarca granosa extract Haishengsu is another strategy used ${ }^{[7,99-101]}$. Sorcin-specific miR-1 or antagomiR-1 are possibly the most specific ways to target Sorcin ${ }^{[36]}$, together with approaches of Sorcin silencing or the use of Crispr-Cas9.

\section{THE SRI GENE RESIDES IN THE ABCB1 AMPLICON: GENE COAMPLIFICATION AND PROTEIN COEXPRESSION IN MDR TUMORS}

Sorcin was identified as "resistance-related", because it's encoded by a gene co-amplified with ABCB1, i.e., the most important broad substrate specificity ATP-dependent efflux pump, able to pump xenobiotics (such as toxins or drugs) out of cells ${ }^{[65]}$.

The human $\mathrm{ABCB} 1$ gene, in the chromosomal region $7 \mathrm{q} 21.1^{[102]}$, confers $\mathrm{MDR}$ when overexpressed or amplified $^{[102-106]}$; increased $\mathrm{ABCB} 1$ expression upon treatment with chemotherapeutic drug has been largely reported in the last thirty years ${ }^{[107-115]}$.

In many types of cancers, amplification of the chromosome 7q21 region containing genes of $\mathrm{ABCB} 1$ and Sorcin, has been reported in MD-resistant cell lines as neuroblastoma ${ }^{[116]}$, lung cancer cells ${ }^{[117]}$ and leukemia cells ${ }^{[118]}$. Often, genomic instability and chromosomal rearrangements result in genomic amplification, yielding an increase in the $\mathrm{ABCB} 1$ gene copy number and transactivation of $\mathrm{ABCB} 1$ overexpression $^{[119-124]}$.

Several genes surrounding $\mathrm{ABCB} 1$ have recently been identified as contributors to the MD-resistant phenotype when overexpressed or amplified together with $A B C B 1$ or suppressed in resistance-induced cancer cell lines. Many studies describe a genomic amplification of chromosome 7q21.12 region, where $\mathrm{ABCB} 1$ and other MDR-related genes reside [Figure 6], in MD-resistant tumors; the MD-resistant phenotype depends at least in part on the amplification and/or overexpression of these genes ${ }^{[1,6,106,116-118,125-136]}$. The ABCB1 amplicon in the chromosomal region 7q21.12 is formed by the SRI, ADAM22, DBF4, SLC25A40, RUNDC3B (RPIP9), ABCB1, ABCB4, CROT, TP53TG1 lncRNA, TMEM243 (MGC4175) and DMTF1 (DMP1) genes [Figure 6] ${ }^{[137]}$, that have been associated with tumorigenesis and MDR; DBF4 and Sorcin, among these genes, are possibly the most important contributors to the MD-resistant phenotype, together 


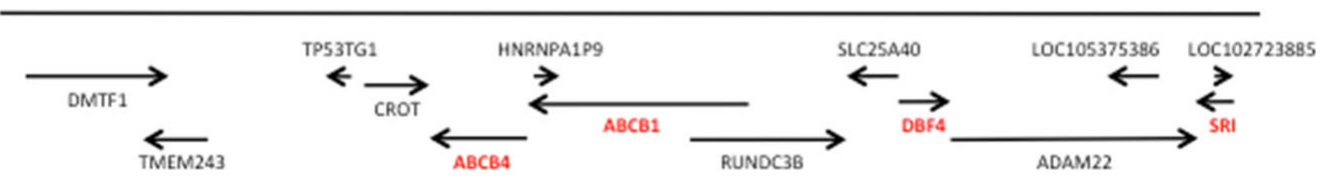

Figure 6. The ABCB1 amplicon is formed by the genes SRI, ADAM22, DBF4, SLC25A40, RUNDC3B (RPIP9), ABCB1, ABCB4, CROT, TP53TG1 IncRNA, TMEM243 (MGC4175) and DMTF1 (DMP1)

with the efflux pumps $\mathrm{ABCB} 1$ and $\mathrm{ABCB} 4$ (MDR3): DBF4 and Sorcin are both important markers of poor prognosis and drivers of MDR in several types of cancers, acting on different (although partially overlapping) mechanisms with respect to $\mathrm{ABCB} 1^{[137]}$.

In lung cancer cells with acquired paclitaxel resistance, the 7.q21.12 region is amplified, but $\mathrm{ABCB} 1$ expression is increased up to 1000-fold, showing a discrepancy between expression level and gene copy number ${ }^{[133]}$. A regional activation on chromosome 7q21.11-13, of about 22 co-expressed genes over an area of $8 \mathrm{Mb}$, was identified in taxane-induced MD-resistant ovarian tumor cells; the amplified region (with increase in genes copy number) included ABCB1, MGC4175 (TMEM243), DMTF1, CROT, ABCB1, ABCB4, ADAM22, RUNDC3B, DBF4 and SRI ${ }^{[138]}$. A gene copy number gain on chromosome 7q21.12, including the genes $\mathrm{ABCB} 1, \mathrm{ABCB} 4, \mathrm{SRI}, \mathrm{DMTF} 1, \mathrm{SLC} 25 \mathrm{~A} 40$ and CROT, was observed in taxane-resistant breast tumor cell lines ${ }^{[129]}$. On the other hand, MD-resistant ovarian tumor cells containing a translocation generating fused $\mathrm{ABCB} 1$ and SLC25A40 genes, determining the overexpression of ABCB1, were found only in MDresistant cancers, while no evidence of this event occurs in drug-sensitive cancer cells ${ }^{[131]}$. Deletions in the $\mathrm{ABCB} 1$ genes locus in breast cancer patients determine a 2-8-fold decreased expression of these MDR locus-related genes; cancer patients harboring these deletions display a better response to neoadjuvant chemotherapy ${ }^{[130]}$.

In addition to genomic rearrangements and presence of high copy, other mechanisms may contribute to increased gene expression, such as transcriptional upregulation, mRNA stabilization, post-transcriptional regulation and epigenetic modifications. Non-coding RNAs, such as miRNAs and long non-coding RNAs, can possibly exert post-transcriptionally regulate oncogene functions on cancer cells, resulting in metastatic or drug-resistant phenotypes: the long non-coding RNA TP53TG1, present in the chromosomal region 7.q21.12, is down-regulated in A549 cisplatin-resistant lung cancer cells ${ }^{[139]}$; miR-1, specifically targeting $\operatorname{Sorcin}^{[36]}$, is frequently downregulated in various types of cancer, such as lung cancer, colon cancer, genitourinary cancer, head and neck tumor, thyroid cancer and sarcoma; low miR-1 levels have been shown to be associated with chemosensitivity ${ }^{[140,141]}$.

\section{CONCLUSION}

Sorcin has an important role as a modulator of cellular calcium homeostasis, acting on $\mathrm{Ca}^{2+}$ channels, exchangers and pumps, thereby regulating ER and mitochondrial $\mathrm{Ca}^{2+}$ levels, reducing ER stress and mitochondrial dysfunction, and protecting the cell from apoptosis.

Sorcin is highly expressed in the heart and in the brain, it is overexpressed in cancers and other pathological conditions, and plays important roles in the onset of cancer, cardiac diseases and possibly neurodegenerative diseases. 
Sorcin is overexpressed in MD-resistant cancer cells, co-amplified with ABCB1, ABCB4 and other proteins involved in the resistance to chemotherapy in cancer cells. Sorcin overexpression induces resistance to many different chemotherapeutic drugs, while Sorcin silencing reverts drug resistance, by acting on many pathways.

Sorcin is therefore an important MDR marker and may represent a therapeutic target for reversing MDR.

\section{DECLARATIONS}

\section{Acknowledgments}

We acknowledge "Quality methods for Design of Experiments in Scientific Research", in the FaReBio di Qualità Project: Quality and Project Management OpenLab: qPMO CNR; the Flagship Project Nanomax: "NADINE: Nanotechnology-based Diagnostics In Neurological diseases and Experimental oncology"; PRIN 20154JJPP MIUR; Progetto Ricerca Finalizzata Min. Salute RF-2016-02364123 RAREST-JHD.

\section{Authors' contributions}

Conception of the work: Ilari A, Colotti G

Draft and revision of the work: Genovese I, Ilari A, Battista T, Chiarini V, Fazi F, Fiorillo A, Colotti G

\section{Availability of data and materials}

Not applicable.

\section{Financial support and sponsorship}

None.

\section{Conflicts of interest}

All authors declared that there are no conflicts of interest.

\section{Ethical approval and consent to participate}

Not applicable.

\section{Consent for publication}

Not applicable.

\section{Copyright}

(c) The Author(s) 2018.

\section{REFERENCES}

1. Van der Bliek AM, Meyers MB, Biedler JL, Hes E, Borst P. A 22-kd protein (sorcin/V19) encoded by an amplified gene in multidrugresistant cells, is homologous to the calcium-binding light chain of calpain. EMBO J 1986;5:3201-8.

2. Colotti G, Poser E, Fiorillo A, Genovese I, Chiarini V, Ilari A. Sorcin, a calcium binding protein involved in the multidrug resistance mechanisms in cancer cells. Molecules 2014;19:13976-89.

3. Hansen C, Tarabykina S, la Cour JM, Lollike K, Berchtold MW. The PEF family proteins sorcin and grancalcin interact in vivo and in vitro. FEBS Lett 2003;545:151-4.

4. Maki M, Kitaura Y, Satoh H, Ohkouchi S, Shibata H. Structures, functions and molecular evolution of the penta-EF-hand Ca2+-binding proteins. Biochim Biophys Acta 2002;1600:51-60.

5. Ilari A, Fiorillo A, Poser E, Lalioti VS, Sundell GN, Ivarsson Y, Genovese I, Colotti G. Structural basis of Sorcin-mediated calciumdependent signal transduction. Sci Rep 2015;5:16828.

6. Ilari A, Johnson KA, Nastopoulos V, Verzili D, Zamparelli C, Colotti G, Tsernoglou D, Chiancone E. The crystal structure of the sorcin calcium binding domain provides a model of Ca2+-dependent processes in the full-length protein. J Mol Biol 2002;317:447-58. 
7. Colotti G, Zamparelli C, Verzili D, Mella M, Loughrey CM, Smith GL, Chiancone E. The W105G and W99G sorcin mutants demonstrate the role of the $\mathrm{D}$ helix in the $\mathrm{Ca}(2+)$-dependent interaction with annexin VII and the cardiac ryanodine receptor. Biochemistry 2006;45:12519-29.

8. Mella M, Colotti G, Zamparelli C, Verzili D, Ilari A, Chiancone E. Information transfer in the penta-EF-hand protein sorcin does not operate via the canonical structural/functional pairing. A study with site-specific mutants. J Biol Chem 2003;278:24921-8.

9. Zamparelli C, Ilari A, Verzili D, Giangiacomo L, Colotti G, Pascarella S, Chiancone E. Structure-function relationships in sorcin, a member of the penta EF-hand family. Interaction of sorcin fragments with the ryanodine receptor and an Escherichia coli model system. Biochemistry 2000;39:658-66.

10. Lalioti VS, Ilari A, O'Connell DJ, Poser E, Sandoval IV, Colotti G. Sorcin links calcium signaling to vesicle trafficking, regulates Pololike kinase 1 and is necessary for mitosis. PLoS One 2014;9:e85438.

11. Maddalena F, Sisinni L, Lettini G, Condelli V, Matassa DS, Piscazzi A, Amoroso MR, La Torre G, Esposito F, Landriscina M. Resistance to paclitxel in breast carcinoma cells requires a quality control of mitochondrial antiapoptotic proteins by TRAP1. Mol Oncol 2013;7:895-906.

12. Clapham DE. Calcium signaling. Cell 2007;131:1047-58.

13. Fowler MR, Colotti G, Chiancone E, Higuchi Y, Seidler T, Smith GL. Complex modulation of L-type Ca(2+) current inactivation by sorcin in isolated rabbit cardiomyocytes. Pflugers Arch 2009;457:1049-60.

14. Fowler MR, Colotti G, Chiancone E, Smith GL, Fearon IM. Sorcin modulates cardiac L-type Ca2+ current by functional interaction with the alpha1C subunit in rabbits. Exp Physiol 2008;93:1233-8.

15. Franceschini S, Ilari A, Verzili D, Zamparelli C, Antaramian A, Rueda A, Valdivia HH, Chiancone E, Colotti G. Molecular basis for the impaired function of the natural F112L sorcin mutant: X-ray crystal structure, calcium affinity, and interaction with annexin VII and the ryanodine receptor. FASEB J 2008;22:295-306.

16. Matsumoto T, Hisamatsu Y, Ohkusa T, Inoue N, Sato T, Suzuki S, Ikeda Y, Matsuzaki M. Sorcin interacts with sarcoplasmic reticulum $\mathrm{Ca}(2+)$-ATPase and modulates excitation-contraction coupling in the heart. Basic Res Cardiol 2005;100:250-62.

17. Meyers MB, Fischer A, Sun YJ, Lopes CM, Rohacs T, Nakamura TY, Zhou YY, Lee PC, Altschuld RA, McCune SA, Coetzee WA, Fishman GI. Sorcin regulates excitation-contraction coupling in the heart. J Biol Chem 2003;278:28865-71.

18. Suarez J, McDonough PM, Scott BT, Suarez-Ramirez A, Wang H, Fricovsky ES, Dillmann WH. Sorcin modulates mitochondrial $\mathrm{Ca}(2+)$ handling and reduces apoptosis in neonatal rat cardiac myocytes. Am J Physiol Cell Physiol 2013;304:C248-56.

19. Zamparelli C, Macquaide N, Colotti G, Verzili D, Seidler T, Smith GL, Chiancone E. Activation of the cardiac $\mathrm{Na}(+)-\mathrm{Ca}(2+)$ exchanger by sorcin via the interaction of the respective $\mathrm{Ca}(2+)$-binding domains. J Mol Cell Cardiol 2010;49:132-41.

20. Marmugi A, Parnis J, Chen X, Carmichael L, Hardy J, Mannan N, Marchetti P, Piemonti L, Bosco D, Johnson P, Shapiro JA, CrucianiGuglielmacci C, Magnan C, Ibberson M, Thorens B, Valdivia HH, Rutter GA, Leclerc I. Sorcin links pancreatic $\beta$-cell lipotoxicity to ER Ca2+ stores. Diabetes 2016;65:1009-21.

21. Noordeen NA, Meur G, Rutter GA, Leclerc I. Glucose-induced nuclear shuttling of ChREBP is mediated by sorcin and $\mathrm{Ca}(2+)$ ions in pancreatic beta-cells. Diabetes 2012;61:574-85.

22. Hu Y, Cheng X, Li S, Zhou Y, Wang J, Cheng T, Yang M, Xiong D. Inhibition of sorcin reverses multidrug resistance of K562/A02 cells and MCF-7/A02 cells via regulating apoptosis-related proteins. Cancer Chemother Pharmacol 2013;72:789-98.

23. Anthony DF, Beattie J, Paul A, Currie S. Interaction of calcium/calmodulin-dependent protein kinase IIdeltaC with sorcin indirectly modulates ryanodine receptor function in cardiac myocytes. J Mol Cell Cardiol 2007;43:492-503.

24. Salzer U, Hinterdorfer P, Hunger U, Borken C, Prohaska R. Ca(++)-dependent vesicle release from erythrocytes involves stomatinspecific lipid rafts, synexin (annexin VII), and sorcin. Blood 2002;99:2569-77.

25. Brownawell AM, Creutz CE. Creutz, Calcium-dependent binding of sorcin to the N-terminal domain of synexin (annexin VII). J Biol Chem 1997;272:22182-90.

26. Tomas A, Futter C, Moss SE. Moss, Annexin 11 is required for midbody formation and completion of the terminal phase of cytokinesis. J Cell Biol 2004;165:813-22.

27. Lai RC, Chen TS, Lim SK. Mesenchymal stem cell exosome: a novel stem cell-based therapy for cardiovascular disease. Regen Med 2011;6:481-92.

28. Buschow SI, van Balkom BW, Aalberts M, Heck AJ, Wauben M, Stoorvogel W. MHC class II-associated proteins in B-cell exosomes and potential functional implications for exosome biogenesis. Immunol Cell Biol 2010;88:851-6.

29. Demory Beckler M, Higginbotham JN, Franklin JL, Ham AJ, Halvey PJ, Imasuen IE, Whitwell C, Li M, Liebler DC, Coffey RJ. Proteomic analysis of exosomes from mutant KRAS colon cancer cells identifies intercellular transfer of mutant KRAS. Mol Cell Proteomics 2013;12:343-55.

30. Gonzales PA, Pisitkun T, Hoffert JD, Tchapyjnikov D, Star RA, Kleta R, Wang NS, Knepper MA. Large-scale proteomics and phosphoproteomics of urinary exosomes. J Am Soc Nephrol 2009;20:363-79.

31. Keerthikumar S, Gangoda L, Liem M, Fonseka P, Atukorala I, Ozcitti C, Mechler A, Adda CG, Ang CS, Mathivanan S. Proteogenomic analysis reveals exosomes are more oncogenic than ectosomes. Oncotarget 2015;6:15375-96.

32. Kharaziha P, Chioureas D, Rutishauser D, Baltatzis G, Lennartsson L, Fonseca P, Azimi A, Hultenby K, Zubarev R, Ullén A, Yachnin J, Nilsson S, Panaretakis T. Molecular profiling of prostate cancer derived exosomes may reveal a predictive signature for response to docetaxel. Oncotarget 2015;6:21740-54.

33. Liang B, Peng P, Chen S, Li L, Zhang M, Cao D, Yang J, Li H, Gui T, Li X, Shen K. Characterization and proteomic analysis of ovarian 
cancer-derived exosomes. J Proteomics 2013;80:171-82.

34. Pienimaeki-Roemer A, Kuhlmann K, Böttcher A, Konovalova T, Black A, Orsó E, Liebisch G, Ahrens M, Eisenacher M, Meyer HE, Schmitz G. Lipidomic and proteomic characterization of platelet extracellular vesicle subfractions from senescent platelets. Transfusion 2015;55:507-21.

35. Pisitkun T, Shen RF, Knepper MA. Identification and proteomic profiling of exosomes in human urine. Proc Natl Acad Sci U S A 2004;101:13368-73.

36. Ali R, Huang Y, Maher SE, Kim RW, Giordano FJ, Tellides G, Geirsson A. miR-1 mediated suppression of Sorcin regulates myocardial contractility through modulation of Ca2+ signaling. J Mol Cell Cardiol 2012;52:1027-37.

37. Bers DM, Despa S, Bossuyt J. Regulation of Ca2+ and Na+ in normal and failing cardiac myocytes. Ann N Y Acad Sci 2006;1080:165-77.

38. Seidler T, Miller SL, Loughrey CM, Kania A, Burow A, Kettlewell S, Teucher N, Wagner S, Kögler H, Meyers MB, Hasenfuss G, Smith GL. Effects of adenovirus-mediated sorcin overexpression on excitation-contraction coupling in isolated rabbit cardiomyocytes. Circ Res 2003;93:132-9.

39. Lokuta AJ, Meyers MB, Sander PR, Fishman GI, Valdivia HH. Modulation of cardiac ryanodine receptors by sorcin. J Biol Chem 1997;272:25333-8.

40. Collis LP, Meyers MB, Zhang J, Phoon CK, Sobie EA, Coetzee WA, Fishman GI. Expression of a sorcin missense mutation in the heart modulates excitation-contraction coupling. FASEB J 2007;21:475-87.

41. Farrell EF, Antaramian A, Rueda A, Gómez AM, Valdivia HH. Sorcin inhibits calcium release and modulates excitation-contraction coupling in the heart. J Biol Chem 2003;278:34660-6.

42. Frank KF, Bölck B, Ding Z, Krause D, Hattebuhr N, Malik A, Brixius K, Hajjar RJ, Schrader J, Schwinger RH. Overexpression of sorcin enhances cardiac contractility in vivo and in vitro. J Mol Cell Cardiol 2005;38:607-15.

43. Suarez J, Belke DD, Gloss B, Dieterle T, McDonough PM, Kim YK, Brunton LL, Dillmann WH. In vivo adenoviral transfer of sorcin reverses cardiac contractile abnormalities of diabetic cardiomyopathy. Am J Physiol Heart Circ Physiol 2004;286:H68-75.

44. Chen X, Weber C, Farrell ET, Alvarado FJ, Zhao YT, Gómez AM, Valdivia HH. Sorcin ablation plus beta-adrenergic stimulation generate an arrhythmogenic substrate in mouse ventricular myocytes. J Mol Cell Cardiol 2018;114:199-210.

45. Alzheimer's Association Calcium Hypothesis Workgroup. Calcium hypothesis of Alzheimer's disease and brain aging: a framework for integrating new evidence into a comprehensive theory of pathogenesis. Alzheimers Dement 2017;13:178-182.e17.

46. Surmeier DJ, Halliday GM, Simuni T. Calcium, mitochondrial dysfunction and slowing the progression of Parkinson's disease. Exp Neurol 2017;298:202-9.

47. Del Prete D, Checler F, Chami M. Ryanodine receptors: physiological function and deregulation in Alzheimer disease. Mol Neurodegener 2014;9:21.

48. Pack-Chung E, Meyers MB, Pettingell WP, Moir RD, Brownawell AM, Cheng I, Tanzi RE, Kim TW. Presenilin 2 interacts with sorcin, a modulator of the ryanodine receptor. J Biol Chem 2000; 275:14440-5.

49. Woods WS, Boettcher JM, Zhou DH, Kloepper KD, Hartman KL, Ladror DT, Qi Z, Rienstra CM, George JM. Conformation-specific binding of alpha-synuclein to novel protein partners detected by phage display and NMR spectroscopy. J Biol Chem 2007;282:34555-67.

50. Tu H, Nelson O, Bezprozvanny A, Wang Z, Lee SF, Hao YH, Serneels L, De Strooper B, Yu G, Bezprozvanny I. Presenilins form ER Ca2+ leak channels, a function disrupted by familial Alzheimer's disease-linked mutations. Cell 2006;126:981-93.

51. Takeda T, Asahi M, Yamaguchi O, Hikoso S, Nakayama H, Kusakari Y, Kawai M, Hongo K, Higuchi Y, Kashiwase K, Watanabe T, Taniike M, Nakai A, Nishida K, Kurihara S, Donoviel DB, Bernstein A, Tomita T, Iwatsubo T, Hori M, Otsu K. Presenilin 2 regulates the systolic function of heart by modulating Ca2+ signaling. FASEB J 2005;19:2069-71.

52. Kim SI, Lee HJ, Kim SS, Kwon YS, Chun W. Sequestration of sorcin by aberrant forms of tau results in the defective calcium homeostasis. Korean J Physiol Pharmacol 2016;20:387-97.

53. Xie H, Chang M, Hu X, Wang D, Tian M, Li G, Jiang H, Wang Y, Dong Z, Zhang Y, Hu L. Proteomics analysis of MPP+-induced apoptosis in SH-SY5Y cells. Neurol Sci 2011;32:221-8.

54. Werner CJ, Heyny-von Haussen R, Mall G, Wolf S. Proteome analysis of human substantia nigra in Parkinson's disease. Proteome Sci 2008;6:8.

55. Jin J, Hulette C, Wang Y, Zhang T, Pan C, Wadhwa R, Zhang J. Proteomic identification of a stress protein, mortalin/mthsp70/GRP75: relevance to Parkinson disease. Mol Cell Proteomics 2006;5:1193-204.

56. Andreev VP, Petyuk VA, Brewer HM, Karpievitch YV, Xie F, Clarke J, Camp D, Smith RD, Lieberman AP, Albin RL, Nawaz Z, El Hokayem J, Myers AJ. Label-free quantitative LC-MS proteomics of Alzheimer's disease and normally aged human brains. J Proteome Res 2012;11:3053-67.

57. Musunuri S, Wetterhall M, Ingelsson M, Lannfelt L, Artemenko K, Bergquist J, Kultima K, Shevchenko G. Quantification of the brain proteome in Alzheimer's disease using multiplexed mass spectrometry. J Proteome Res 2014;13:2056-68.

58. Seyfried NT, Dammer EB, Swarup V, Nandakumar D, Duong DM, Yin L, Deng Q, Nguyen T, Hales CM, Wingo T, Glass J, Gearing M, Thambisetty M, Troncoso JC, Geschwind DH, Lah JJ, Levey AI. A multi-network approach identifies protein-specific co-expression in asymptomatic and symptomatic Alzheimer's disease. Cell Syst 2017;4:60-72.e4.

59. Drummond E, Nayak S, Faustin A, Pires G, Hickman RA, Askenazi M, Cohen M, Haldiman T, Kim C, Han X, Shao Y, Safar JG, Ueberheide B, Wisniewski T. Proteomic differences in amyloid plaques in rapidly progressive and sporadic Alzheimer's disease. Acta Neuropathol 2017;133:933-54.

60. Hondius DC, Eigenhuis KN, Morrema THJ, van der Schors RC, van Nierop P, Bugiani M, Li KW, Hoozemans JJM, Smit AB, 
Rozemuller AJM. Proteomics analysis identifies new markers associated with capillary cerebral amyloid angiopathy in Alzheimer's disease. Acta Neuropathol Commun 2018;6:46.

61. Umoh ME, Dammer EB, Dai J, Duong DM, Lah JJ, Levey AI, Gearing M, Glass JD, Seyfried NT. A proteomic network approach across the ALS-FTD disease spectrum resolves clinical phenotypes and genetic vulnerability in human brain. EMBO Mol Med 2018;10:48-62.

62. Kalathur RK, Giner-Lamia J, Machado S, Barata T, Ayasolla KR, Futschik ME. The unfolded protein response and its potential role in Huntington's disease elucidated by a systems biology approach. Version 2. F1000Res 2015;4:103.

63. Gracy KN, Clarke CL, Meyers MB, Pickel VM. N-methyl-D-aspartate receptor 1 in the caudate-putamen nucleus: ultrastructural localization and co-expression with sorcin, a 22,000 mol. wt calcium binding protein. Neuroscience 1999;90:107-17.

64. Clemen CS, Herr C, Hövelmeyer N, Noegel AA. The lack of annexin A7 affects functions of primary astrocytes. Exp Cell Res 2003;291:406-14.

65. Meyers MB, Biedler JL. Increased synthesis of a low molecular weight protein in vincristine-resistant cells. Biochem Biophys Res Commun 1981;99:228-35.

66. Van der Bliek AM, Baas F, Van der Velde-Koerts T, Biedler JL, Meyers MB, Ozols RF, Hamilton TC, Joenje H, Borst P. Genes amplified and overexpressed in human multidrug-resistant cell lines. Cancer Res 1988;48:5927-32.

67. Deng L, Su T, Leng A, Zhang X, Xu M, Yan L, Gu H, Zhang G. Upregulation of soluble resistance-related calcium-binding protein (sorcin) in gastric cancer. Med Oncol 2010;27:1102-8.

68. Padar S, van Breemen C, Thomas DW, Uchizono JA, Livesey JC, Rahimian R. Differential regulation of calcium homeostasis in adenocarcinoma cell line A549 and its Taxol-resistant subclone. Br J Pharmacol 2004;142:305-16.

69. Qi J, Liu N, Zhou Y, Tan Y, Cheng Y, Yang C, Zhu Z, Xiong D. Overexpression of sorcin in multidrug resistant human leukemia cells and its role in regulating cell apoptosis. Biochem Biophys Res Commun 2006;349:303-9.

70. Qu Y, Yang Y, Liu B, Xiao W. Comparative proteomic profiling identified sorcin being associated with gemcitabine resistance in nonsmall cell lung cancer. Med Oncol 2010;27:1303-8.

71. Tan Y, Li G, Zhao C, Wang J, Zhao H, Xue Y, Han M, Yang C. Expression of sorcin predicts poor outcome in acute myeloid leukemia. Leuk Res 2003;27:125-31.

72. Yamagishi N, Nakao R, Kondo R, Nishitsuji M, Saito Y, Kuga T, Hatayama T, Nakayama Y. Increased expression of sorcin is associated with multidrug resistance in leukemia cells via up-regulation of MDR1 expression through cAMP response element-binding protein. Biochem Biophys Res Commun 2014;448:430-6.

73. Yang YX, Chen ZC, Zhang GY, Yi H, Xiao ZQ. A subcelluar proteomic investigation into vincristine-resistant gastric cancer cell line. J Cell Biochem 2008;104:1010-21.

74. Zhou Y, Xu Y, Tan Y, Qi J, Xiao Y, Yang C, Zhu Z, Xiong D. Sorcin, an important gene associated with multidrug-resistance in human leukemia cells. Leuk Res 2006;30:469-76.

75. Gao Y, Li W, Liu X, Gao F, Zhao X. Reversing effect and mechanism of soluble resistance-related calcium-binding protein on multidrug resistance in human lung cancer A549/DDP cells. Mol Med Rep 2015;11:2118-24.

76. Sun Y, Wang C, Meng Q, Liu Z, Huo X, Sun P, Sun H, Ma X, Peng J, Liu K. Targeting P-glycoprotein and SORCIN: dihydromyricetin strengthens anti-proliferative efficiency of adriamycin via MAPK/ERK and Ca2+-mediated apoptosis pathways in MCF-7/ADR and K562/ADR. J Cell Physiol 2018;233: 3066-79.

77. Dabaghi M, Rahgozar S, Moshtaghian J, Moafi A, Abedi M, Pourabutaleb E. Overexpression of SORCIN is a prognostic biomarker for multidrug-resistant pediatric acute lymphoblastic leukemia and correlates with upregulated MDR1/P-gp. Genet Test Mol Biomarkers 2016;20:516-21.

78. Maddalena F, Laudiero G, Piscazzi A, Secondo A, Scorziello A, Lombardi V, Matassa DS, Fersini A, Neri V, Esposito F, Landriscina M. Sorcin induces a drug-resistant phenotype in human colorectal cancer by modulating $\mathrm{Ca}(2+)$ homeostasis. Cancer Res 2011;71:7659-69.

79. Tong W, Sun D, Wang Q, Suo J. Sorcin enhances metastasis and promotes epithelial-to-mesenchymal transition of colorectal cancer. Cell Biochem Biophys 2015;72:453-9.

80. Mangia A, Caldarola L, Dell'Endice S, Scarpi E, Saragoni L, Monti M, Santini D, Brunetti O, Simone G, Silvestris N. The potential predictive role of nuclear NHERF1 expression in advanced gastric cancer patients treated with epirubicin/oxaliplatin/capecitabine first line chemotherapy. Cancer Biol Ther 2015;16:1140-7.

81. Xu P, Jiang YF, Wang JH. shRNA-mediated silencing of sorcin increases drug chemosensitivity in myeloma KM3/DDP and U266/ADM cell lines. Int J Clin Exp Pathol 2015;8:2300-10.

82. Pomeroy SL, Tamayo P, Gaasenbeek M, Sturla LM, Angelo M, McLaughlin ME, Kim JY, Goumnerova LC, Black PM, Lau C, Allen JC, Zagzag D, Olson JM, Curran T, Wetmore C, Biegel JA, Poggio T, Mukherjee S, Rifkin R, Califano A, Stolovitzky G, Louis DN, Mesirov JP, Lander ES, Golub TR. Prediction of central nervous system embryonal tumour outcome based on gene expression. Nature 2002;415:436-42.

83. French PJ, Swagemakers SM, Nagel JH, Kouwenhoven MC, Brouwer E, van der Spek P, Luider TM, Kros JM, van den Bent MJ, Sillevis Smitt PA. Gene expression profiles associated with treatment response in oligodendrogliomas. Cancer Res 2005;65:11335-44.

84. Shai R, Shi T, Kremen TJ, Horvath S, Liau LM, Cloughesy TF, Mischel PS, Nelson SF. Gene expression profiling identifies molecular subtypes of gliomas. Oncogene 2003;22:4918-23.

85. Sun L, Hui AM, Su Q, Vortmeyer A, Kotliarov Y, Pastorino S, Passaniti A, Menon J, Walling J, Bailey R, Rosenblum M, Mikkelsen T, Fine HA. Neuronal and glioma-derived stem cell factor induces angiogenesis within the brain. Cancer Cell 2006;9:287-300.

86. Yokota T, Kouno J, Adachi K, Takahashi H, Teramoto A, Matsumoto K, Sugisaki Y, Onda M, Tsunoda T. Identification of histological 
markers for malignant glioma by genome-wide expression analysis: dynein, alpha-PIX and sorcin. Acta Neuropathol 2006;111:29-38.

87. Genovese I, Fiorillo A, Ilari A, Masciarelli S, Fazi F, Colotti G. Binding of doxorubicin to Sorcin impairs cell death and increases drug resistance in cancer cells. Cell Death Dis 2017;8:e2950.

88. Hamada H, Okochi E, Oh-hara T, Tsuruo T. Purification of the Mr 22,000 calcium-binding protein (sorcin) associated with multidrug resistance and its detection with monoclonal antibodies. Cancer Res 1988;48:3173-8.

89. He Q, Zhang G, Hou D, Leng A, Xu M, Peng J, Liu T. Overexpression of sorcin results in multidrug resistance in gastric cancer cells with up-regulation of P-gp. Oncol Rep 2011;25:237-43.

90. Kawakami M, Nakamura T, Okamura N, Komoto C, Markova S, Kobayashi H, Hashimoto N, Okumura K, Sakaeda T. Knock-down of sorcin induces up-regulation of MDR1 in HeLa cells. Biol Pharm Bull 2007;30:1065-73.

91. Liu X, Chen L, Feng B, Liu G. Reversing effect of sorcin in the drug resistance of human nasopharyngeal carcinoma. Anat Rec (Hoboken) 2014;297:215-21.

92. Parekh HK, Deng HB, Choudhary K, Houser SR, Simpkins H. Overexpression of sorcin, a calcium-binding protein, induces a low level of paclitaxel resistance in human ovarian and breast cancer cells. Biochem Pharmacol 2002;63:1149-58.

93. Gong Z, Sun P, Chu H, Zhu H, Sun D, Chen J. Overexpression of sorcin in multidrug-resistant human breast cancer. Oncol Lett 2014;8:2393-8.

94. Hu Y, Li S, Yang M, Yan C, Fan D, Zhou Y, Zhang Y, Yagüe E, Xiong D. Sorcin silencing inhibits epithelial-to-mesenchymal transition and suppresses breast cancer metastasis in vivo. Breast Cancer Res Treat 2014;143:287-99.

95. Tuo H, Shu F, She S, Yang M, Zou XQ, Huang J, Hu HD, Hu P, Ren H, Peng SF, Yang YX. Sorcin induces gastric cancer cell migration and invasion contributing to STAT3 activation. Oncotarget 2017;8:104258-71.

96. Li X, Liu Y, Wang Y, Liu J, Li X, Cao H, Gao X, Zheng SJ. Negative regulation of hepatic inflammation by the soluble resistancerelated calcium-binding protein via signal transducer and activator of transcription 3. Front Immunol 2017;8:709.

97. Lei X, Liang Y, Chen J, Xiao S, Lei J, Li J, Duanmu J, Jiang Q, Liu D, Tang C, Li T. Sorcin predicts poor prognosis and promotes metastasis by facilitating epithelial-mesenchymal transition in hepatocellular carcinoma. Sci Rep 2017;7:10049.

98. Gupta K, Sirohi VK, Kumari S, Shukla V, Manohar M, Popli P, Dwivedi A. Sorcin is involved during embryo implantation via activating VEGF/PI3K/Akt pathway in mice. J Mol Endocrinol 2018;60:119-132.

99. Li GY, Zhang L, Liu JZ, Chen SG, Xiao TW, Liu GZ, Wang JX, Wang LX, Hou M. Marine drug Haishengsu increases chemosensitivity to conventional chemotherapy and improves quality of life in patients with acute leukemia. Biomed Pharmacother 2016;81:160-5.

100. Sun Y, Wang C, Meng Q, Liu Z, Huo X, Sun P, Sun H, Ma X, Peng J, Liu K. Targeting P-glycoprotein and SORCIN: Dihydromyricetin strengthens anti-proliferative efficiency of adriamycin via MAPK/ERK and $\mathrm{Ca}(2+)$-mediated apoptosis pathways in MCF-7/ADR and K562/ADR. J Cell Physiol 2018;233:3066-79.

101. Li GY, Liu JZ, Zhang B, Yang M, Chen SG, Hou M, Wang LX. Tegillarca granosa extract Haishengsu (HSS) suppresses expression of mdr1, BCR/ABL and sorcin in drug-resistant K562/ADM tumors in mice. Adv Med Sci 2013;58:112-7.

102. Callen DF, Baker E, Simmers RN, Seshadri R, Roninson IB. Localization of the human multiple drug resistance gene, MDR1, to 7q21.1. Hum Genet 1987;77:142-4.

103. Fojo AT, Ueda K, Slamon DJ, Poplack DG, Gottesman MM, Pastan I. Expression of a multidrug-resistance gene in human tumors and tissues. Proc Natl Acad Sci U S A 1987;84:265-9.

104. Schoenlein PV. Molecular cytogenetics of multiple drug resistance. Cytotechnology 1993;12:63-89.

105. Scotto KW, Biedler JL, Melera PW. Amplification and expression of genes associated with multidrug resistance in mammalian cells. Science 1986;232:751-5.

106. Van der Bliek AM, Van der Velde-Koerts T, Ling V, Borst P. Overexpression and amplification of five genes in a multidrug-resistant Chinese hamster ovary cell line. Mol Cell Biol 1986;6:1671-8.

107. Abolhoda A, Wilson AE, Ross H, Danenberg PV, Burt M, Scotto KW. Rapid activation of MDR1 gene expression in human metastatic sarcoma after in vivo exposure to doxorubicin. Clin Cancer Res 1999;5:3352-6.

108. Atalay C, Deliloglu Gurhan I, Irkkan C, Gunduz U. Multidrug resistance in locally advanced breast cancer. Tumour Biol 2006;27:309-18.

109. Brügger D, Brischwein K, Liu C, Bader P, Niethammer D, Gekeler V, Beck JF. Induction of drug resistance and protein kinase C genes in A2780 ovarian cancer cells after incubation with antineoplastic agents at sublethal concentrations. Anticancer Res 2002;22:4229-32.

110. Chin KV, Tanaka S, Darlington G, Pastan I, Gottesman MM. Heat shock and arsenite increase expression of the multidrug resistance (MDR1) gene in human renal carcinoma cells. J Biol Chem 1990;265:221-6.

111. Gekeler V, Frese G, Diddens H, Probst H. Expression of a P-glycoprotein gene is inducible in a multidrug-resistant human leukemia cell line. Biochem Biophys Res Commun 1988;155:754-60.

112. Hu XF, Slater A, Wall DM, Kantharidis P, Parkin JD, Cowman A, Zalcberg JR. Rapid up-regulation of mdr1 expression by anthracyclines in a classical multidrug-resistant cell line. Br J Cancer 1995;71:931-6.

113. Liu ZL, Onda K, Tanaka S, Toma T, Hirano T, Oka K. Induction of multidrug resistance in MOLT-4 cells by anticancer agents is closely related to increased expression of functional P-glycoprotein and MDR1 mRNA. Cancer Chemother Pharmacol 2002;49:391-7.

114. Park J, Shinohara N, Liebert M, Noto L, Flint A, Grossman HB. P-glycoprotein expression in bladder cancer. J Urol 1994;151:43-6.

115. Schneider J, Efferth T, Centeno MM, Mattern J, Rodríguez-Escudero FJ, Volm M. High rate of expression of multidrug resistanceassociated P-glycoprotein in human endometrial carcinoma and normal endometrial tissue. Eur J Cancer 1993;29A:554-8.

116. Flahaut M, Mühlethaler-Mottet A, Martinet D, Fattet S, Bourloud KB, Auderset K, Meier R, Schmutz NB, Delattre O, Joseph JM, Gross N. Molecular cytogenetic characterization of doxorubicin-resistant neuroblastoma cell lines: evidence that acquired multidrug resistance 
results from a unique large amplification of the 7q21 region. Genes Chromosomes Cancer 2006;45:495-508.

117. Kitada K, Yamasaki T. The MDR1/ABCB1 regional amplification in large inverted repeats with asymmetric sequences and microhomologies at the junction sites. Cancer Genet Cytogenet 2007;178:120-7.

118. Kadioglu O, Efferth T. Peptide aptamer identified by molecular docking targeting translationally controlled tumor protein in leukemia cells. Invest New Drugs 2016;34:515-21.

119. Chen GK, Lacayo NJ, Durán GE, Wang Y, Bangs CD, Rea S, Kovacs M, Cherry AM, Brown JM, Sikic BI. Preferential expression of a mutant allele of the amplified MDR1 (ABCB1) gene in drug-resistant variants of a human sarcoma. Genes Chromosomes Cancer 2002;34:372-83.

120. Duesberg P, Li R, Sachs R, Fabarius A, Upender MB, Hehlmann R. Cancer drug resistance: the central role of the karyotype. Drug Resist Updat 2007;10:51-8.

121. Katoh H, Shibata T, Kokubu A, Ojima H, Loukopoulos P, Kanai Y, Kosuge T, Fukayama M, Kondo T, Sakamoto M, Hosoda F, Ohki M, Imoto I, Inazawa J, Hirohashi S. Genetic profile of hepatocellular carcinoma revealed by array-based comparative genomic hybridization: identification of genetic indicators to predict patient outcome. J Hepatol 2005;43:863-74.

122. Mickley LA, Spengler BA, Knutsen TA, Biedler JL, Fojo T. Gene rearrangement: a novel mechanism for MDR-1 gene activation. J Clin Invest 1997;99:1947-57.

123. Pang E, Hu Y, Chan KY, Lai PB, Squire JA, Macgregor PF, Beheshti B, Albert M, Leung TW, Wong N. Karyotypic imbalances and differential gene expressions in the acquired doxorubicin resistance of hepatocellular carcinoma cells. Lab Invest 2005;85:664-74.

124. Kim IW, Han N, Kim MG, Kim T, Oh JM. Copy number variability analysis of pharmacogenes in patients with lymphoma, leukemia, hepatocellular, and lung carcinoma using the cancer genome Atlas data. Pharmacogenet Genomics 2015;25:1-7.

125. Bonte D, Lindvall C, Liu H, Dykema K, Furge K, Weinreich M. Cdc7-Dbf4 kinase overexpression in multiple cancers and tumor cell lines is correlated with p53 inactivation. Neoplasia 2008;10:920-31.

126. Chao CC, Ma CM, Lin-Chao S. Co-amplification and over-expression of two mdr genes in a multidrug-resistant human colon carcinoma cell line. FEBS Lett 1991;291:214-8.

127. Cheng AN, Jiang SS, Fan CC, Lo YK, Kuo CY, Chen CH, Liu YL, Lee CC, Chen WS, Huang TS, Wang TY, Lee AY. Increased Cdc7 expression is a marker of oral squamous cell carcinoma and overexpression of Cdc7 contributes to the resistance to DNA-damaging agents. Cancer Lett 2013;337:218-25.

128. Finalet Ferreiro J, Rouhigharabaei L, Urbankova H, van der Krogt JA, Michaux L, Shetty S, Krenacs L, Tousseyn T, De Paepe P, Uyttebroeck A, Verhoef G, Taghon T, Vandenberghe P, Cools J, Wlodarska I. Integrative genomic and transcriptomic analysis identified candidate genes implicated in the pathogenesis of hepatosplenic T-cell lymphoma. PLoS One 2014;9:e102977.

129. Hansen SN, Ehlers NS, Zhu S, Thomsen MB, Nielsen RL, Liu D, Wang G, Hou Y, Zhang X, Xu X, Bolund L, Yang H, Wang J, Moreira J, Ditzel HJ, Brünner N, Schrohl AS, Stenvang J, Gupta R. The stepwise evolution of the exome during acquisition of docetaxel resistance in breast cancer cells. BMC Genomics 2016;17:442.

130. Litviakov NV, Cherdyntseva NV, Tsyganov MM, Slonimskaya EM, Ibragimova MK, Kazantseva PV, Kzhyshkowska J, Choinzonov EL. Deletions of multidrug resistance gene loci in breast cancer leads to the down-regulation of its expression and predict tumor response to neoadjuvant chemotherapy. Oncotarget 2016;7:7829-41.

131. Patch AM, Christie EL, Etemadmoghadam D, Garsed DW, George J, Fereday S, Nones K, Cowin P, Alsop K, Bailey PJ, Kassahn KS, Newell F, Quinn MC, Kazakoff S, Quek K, Wilhelm-Benartzi C, Curry E, Leong HS; Australian Ovarian Cancer Study Group, Hamilton A, Mileshkin L, Au-Yeung G, Kennedy C, Hung J, Chiew YE, Harnett P, Friedlander M, Quinn M, Pyman J, Cordner S, O’Brien P, Leditschke J, Young G, Strachan K, Waring P, Azar W, Mitchell C, Traficante N, Hendley J, Thorne H, Shackleton M, Miller DK, Arnau GM, Tothill RW, Holloway TP, Semple T, Harliwong I, Nourse C, Nourbakhsh E, Manning S, Idrisoglu S, Bruxner TJ, Christ AN, Poudel B, Holmes O, Anderson M, Leonard C, Lonie A, Hall N, Wood S, Taylor DF, Xu Q, Fink JL, Waddell N, Drapkin R, Stronach E, Gabra H, Brown R, Jewell A, Nagaraj SH, Markham E, Wilson PJ, Ellul J, McNally O, Doyle MA, Vedururu R, Stewart C, Lengyel E, Pearson JV, Waddell N, deFazio A, Grimmond SM, Bowtell DD. Whole-genome characterization of chemoresistant ovarian cancer. Nature 2015;521:489-94.

132. Torigoe K, Sato S, Kusaba H, Kohno K, Kuwano M, Okumura K, Green ED, Tsui LC, Scherer SW, Schlessinger D, Wada M. A YACbased contig of $1.5 \mathrm{Mb}$ spanning the human multidrug resistance gene region and delineating the amplification unit in three human multidrug-resistant cell lines. Genome Res 1995;5:233-44.

133. Yabuki N, Sakata K, Yamasaki T, Terashima H, Mio T, Miyazaki Y, Fujii T, Kitada K. Gene amplification and expression in lung cancer cells with acquired paclitaxel resistance. Cancer Genet Cytogenet 2007;173:1-9.

134. Januchowski R, Sterzyńska K, Zawierucha P, Ruciński M, Świerczewska M, Partyka M, Bednarek-Rajewska K, Brązert M, Nowicki $\mathrm{M}$, Zabel M, Klejewski A. Microarray-based detection and expression analysis of new genes associated with drug resistance in ovarian cancer cell lines. Oncotarget 2017;8:49944-58.

135. Lee S, Kim K, Ho JN, Jin H, Byun SS, Lee E. Analysis of resistance-associated gene expression in docetaxel-resistant prostate cancer cells. Oncol Lett 2017;14:3011-8.

136. Sasi NK, Bhutkar A, Lanning NJ, MacKeigan JP, Weinreich M. DDK Promotes Tumor Chemoresistance and Survival via Multiple Pathways. Neoplasia 2017;19:439-50.

137. Genovese I, Ilari A, Assaraf YG, Fazi F, Colotti G. Not only P-glycoprotein: amplification of the ABCB1-containing chromosome region $7 \mathrm{q} 21$ confers multidrug resistance upon cancer cells by coordinated overexpression of an assortment of resistance-related proteins. Drug Resist Updat 2017;32:23-46. 
138. Wang YC, Juric D, Francisco B, Yu RX, Duran GE, Chen GK, Chen X, Sikic BI. Regional activation of chromosomal arm 7q with and without gene amplification in taxane-selected human ovarian cancer cell lines. Genes Chromosomes Cancer 2006;45:365-74.

139. Yang Y, Li H, Hou S, Hu B, Liu J, Wang J. The noncoding RNA expression profile and the effect of lncRNA AK126698 on cisplatin resistance in non-small-cell lung cancer cell. PLoS One 2013;8:e65309.

140. Han C, Yu Z, Duan Z, Kan Q. Role of microRNA-1 in human cancer and its therapeutic potentials. Biomed Res Int 2014;2014:428371.

141. Kim CH, Kim HK, Rettig RL, Kim J, Lee ET, Aprelikova O, Choi IJ, Munroe DJ, Green JE. miRNA signature associated with outcome of gastric cancer patients following chemotherapy. BMC Med Genomics 2011;4:79. 